\title{
The secular religion of evolution(ism)
}

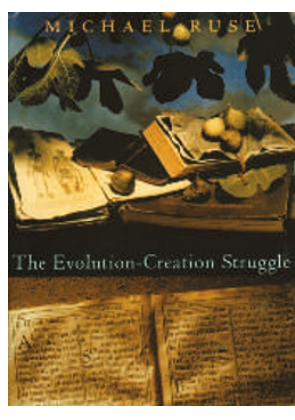

\section{The Evolution-Creation Struggle}

By Michael Ruse

Harvard University Press • 2005

$\$ 25.95 / £ 14.28$

\section{John M. Lynch}

As an undergraduate in Ireland in the mid-80's I came across a copy of Ashley Montagu's book Science and Creationism. Frankly, I felt that I was reading some kind of parody - could there actually be people, in a technologically literate country like the United States, who denied both the fact of evolution and the hypothesis that natural selection was a mechanism for this process? Such opposition was not an issue in Ireland and I could not see why it should be in America. Subsequent experience has taught me that this is sadly the case, and that anti-evolutionists often have understandable reasons for their opposition to Darwinian evolution.

The Montagu volume contained an article by the philosopher and historian Michael Ruse. He described his experiences during the 1981 Arkansas 'Scopes II' trial where he provided Judge William Overton with a somewhat controversial definition of science that formed the basis of the decision to ban 'creation science' from Arkansas public schools. This decision, along with the 1987 Supreme Court ruling in Edwards v Aguilard, marked a sea-change for the anti-evolution movement in America. As a result, creationism itself was forced to evolve and indeed, the resurgence of intelligent design is a clear indication that anti-evolutionism has not died in the United States. With ongoing creationist action at the state and local level in many states in America, the struggle between supporters of evolution and creation is unlikely to disappear soon, and intelligent design also appears to be making some inroads into Europe.

In this relatively short and readable book, The Evolution-Creation Struggle, Ruse sets out his vision of this ongoing struggle between evolution and creation. His broad historical narrative begins with the Enlightenment and discusses the development of evolutionary biology as a fully fledged professional science. Ruse is careful to distinguish between evolution and evolutionism - the former is a professionalized field within biology that deals with facts and observations, the latter is a secular religion of evolutionary philosophical naturalism that smuggles values into evolution. Ruse notes that evolutionism is practiced, if not preached, by many of the most skillful popularizers of evolutionary biology (Richard Dawkins, E.O. Wilson, William D. Hamilton,

John M. Lynch is at the Barrett Honors College and Center for Biology \& Society, Arizona State University, Tempe, AZ 85287-1612, USA.

e-mail: john.lynch@asu.edu
Jerry Coyne, and William Provine are all offered as exemplars). These supporters of evolutionism, Ruse claims, exhibit a world-view that is ultimately optimistic and supports progress. In fact, he sees such individuals as essentially post-millennial; that is, believing that humans can work towards a better future. This is in opposition to pre-millennialists (including advocates of creationism and intelligent design) who, believing in Christian providentialism, hold that human action alone cannot and will not make the world a better place. Ruse thus shifts the 'struggle' from (the traditionally accepted) one of evolution-versus-creation to one of differing visions of the future of humanity.

It would be tempting, and easy, to misread Ruse as saying that evolution is a religion, and I expect creationists will, if past history is any guide, mis-quote portions of this work. Ruse clearly states that evolution is a mature, professional science exhibiting "[p]rediction, consilience, consistency, and fertility". Indeed, Ruse denies these very characteristics to intelligent design, stating "we find no empirical or conceptual reason whatsoever to think of intelligent design theory as genuine science ... [T] $\mathrm{T}$ here are no results. And there are no new predictions leading to new and unexpected discoveries". On this point, I wholeheartedly agree with Ruse.

\section{Ruse's point is clear; "Those of us who love science \\ must do more than simply restate our positions}

$$
\text { or criticize the opposition." }
$$

He also believes that Darwinism - or any other form of evolution - does not entail the secular theology of evolutionism, and that Christianity itself does not entail any form of anti-evolutionism. In short, one can be a Darwinian and a Christian, an observation backed up in the writings of theologian John F. Haught or biologist Kenneth R. Miller. Thus, Ruse sees it as a fatal flaw for supporters of evolution not to realize that there are deeply religious individuals who support evolution but dismiss evolutionism, and he states that evolutionists need to "start thinking about working together ... rather than apart" with such individuals.

Ruse's point is clear; "Those of us who love science must do more than simply restate our positions or criticize the opposition. We must understand our own assumptions and, equally, find out why others have (often) legitimate concerns. This is not a plea for weak-kneed compromise but a more informed and self-aware approach to the issues. First understanding, and then some strategic moves". The evolution-creation struggle has generated more heat than light in the quarter century since the Arkansas trial, and it shows no sign of letting up. Whether Ruse's analysis is ultimately accurate or not, he is correct in claiming that, as educators and evolutionists, we need to be aware of the potential perils of evolutionism. 


\section{nature \\ cell biology}

Owing to a technical error, the pages of this manuscript were originally mis-numbered by a 100 pages. This has now been corrected online. The corrected online manuscript is numbered 100 pages higher than the mis-numbered version. 